\title{
When Christianity and Homosexuality Collide: Understanding the Potential Intrapersonal Conflict
}

\author{
NASRUDIN SUBHI and DAVID GEELAN \\ School of Education, University of Queensland, St. Lucia, Queensland, Australia
}

\begin{abstract}
Reconciling sexual orientation with religious and spiritual beliefs can be challenging for Christian homosexuals, since many Christian churches teach that homosexual behavior is sinful. A qualitative study of 10 male and 10 female Christian homosexuals was conducted via semistructured interviews. This article seeks to explore the potential conflict between Christianity and homosexuality faced by the respondents. Participants' life stories and experiences varied widely. A few respondents were unaffected by the potential conflict between Christianity and homosexuality, however, the majority were affected. Effects included depression, guilt, anxiety, suicidal ideation, and alienation. Implications of the findings for support personnel are included.
\end{abstract}

Attaining a fulfilled religious and spiritual life (if that is something they desire) can be difficult for homosexual people engaging in traditional Christian organizations. This struggle often begins in adolescence, the time when most religious traditions try to nurture (and control) emerging sexuality within the context of religious beliefs (Buchanan, Dzelme, Harris, \& Hecker, 2001). Unfortunately for homosexual young people, support and nurture may not be available within their faith communities, leading to distress, and potentially leaving them less able to embrace their sexuality (Barret \& Barzan, 1996; Barret \& Logan, 2002).

Intrapersonal conflict between Christianity and homosexuality is not a new phenomenon, and there is a developing literature addressing the issue. Rodriguez (2010) offers a good overview of the relevant research.

Since the beginning of Christianity, most Christians have regarded homosexuality as morally wrong, which led to the position upheld today by most mainstream denominations such as Catholic, Orthodox, and also most Evangelical Protestant. According to Western religious views of homosexuality, debate about conflict between Christianity and homosexuality is easier to understand by separating the two main themes that are evident in the literature: nature and scripture. Moon (2002) has proposed two ways of defining nature: "natural" (this word emerged from the arguments based on a language of nature which entails different meanings) as relevant to science, to what may be experimentally observed in the natural world, and "natural" as interpreted from a perspective of morality. Similarly, scripture can be distinguished in two ways: "literalism" (word for word truth) and "contextualism" (truth is bigger than human language and must be understood in the context in which it is read, thus, enabling people to determine the greater truth within). Moon further points out that the focus of people debating the scriptures can be categorized as either modernist (those who believe that science brings more truths than what the scripture offers) or 
fundamentalist (those who believe that the written truths of scripture constitute God's clear and incontestable will for all times).

In recent years, some Christian organizations have propagated a more liberal interpretation of the Scriptures. One such organization is Integrity, which is a nonprofit organization that caters for gay, lesbian, bisexual, transgender, intersex (GLBTI) Episcopalians as well for those who are heterosexual (Integrity USA, 2008). Although Integrity acknowledges that the Bible is used to condemn homosexuality, they stress the idea that Jesus never addressed homosexuality during his time. Since Episcopalians have traditionally viewed scripture, tradition, and reason as the three sources of spiritual authority, it is reasonable to use scientific knowledge and personal experience along with God-given intellect to interpret the Bible (Integrity USA, 2008).

Dignity is a Christian organization that is organized to unite GLBTI Catholics while at the same time promoting reform in the Catholic Church for the acceptance of GLBTI people as "full and equal members of the one Christ" (Dignity USA, 2008). Dignity views homosexuality from a positive perspective, mainly because they argue that the biblical texts have been misinterpreted by scholars and that contextually the "Bible texts do not address adult, loving homosexual relations as we understand them today" (Helminiak, n.d.).

Many homosexual people have felt that they had to completely renounce their Christian identity when they identified as a homosexual. While renouncing religious faith may offer a solution to conflicts for some homosexuals, there are some people for whom both their sexuality and their religious faith are important facets of their lives. These people typically experience significant intrapersonal conflict, and are the focus of the present study. Rodriguez (2010) states:

...the issue of conflict is not just about the clash that can occur between gay and religious identities, but also about the anxiety that arises in a gay or lesbian person experiencing such conflict. (p. 9)

Australia provides a logical setting for this study to be conducted because, in Australia, Christianity is the religion with the greatest number of adherents. Christianity is nominated by $69.7 \%$ of Australians as their religion when compared to other religions as recorded in the 2001 census (Australian Bureau of Statistics, 2006). Despite changing trends, these figures suggest that many gay men and lesbians were raised within some form of Christian tradition.

The struggle for those individuals who identify as same-sex attracted are potentially very difficult, especially if the person belongs to one of the mainstream Christian denominations (Yarhouse, Brooke, Pisano \& Tan, 2005) or comes from a family that upholds the teachings of these denominations (Newman \& Muzzonigro, 1993; Subhi, 2006). It is plausible that a gay or lesbian person growing up in a family with strict and conservative religious beliefs may find himself or herself in a different situation to another homosexual person who is raised in a more religiously liberal family.

The aim of this article is to explore the experiences of gay men and lesbians with respect to conflicts between their Christianity and their homosexuality. In exploring the experiences reported, two specific research questions are addressed: 
1. How have the respondents experienced and attempted to make sense of the potential conflict between their religious/spiritual understandings and their homosexuality?

2. What have been the personal effects on respondents of the conflict between their religious/spiritual understandings and their homosexuality?

\section{REVIEW OF EXISTING EVIDENCE}

Several studies deal with the potential conflicts that arise between Christianity and homosexuality (e.g., Brooke, 2005; Haldeman, 2004; McMinn, 2005; Shuck \& Liddle, 2001; Yarhouse \& Tan, 2005; Yarhouse, Tan, \& Pawlowski, 2005). Several different approaches have been identified in trying to highlight conflicts that occur between Christianity and homosexuality. Rodriguez' (2010) excellent recent review in this journal offers a thoughtful overview of this conflict and suggests ways forward for further research. He reviews the literature around (homo)sexuality and religion more generally, but notes that the majority of the work has been in Western contexts, in relation to Christianity, and with White participants. While Australia is a Western developed country, the present study is believed to be the first of its kind focusing on Australian participants, and therefore offers a complement to the largely U.S.-based literature (with exceptions such as Henrickson [2007]).

Adamczyk and Pitt (2009) offer an excellent review of the ways in which religious and cultural factors shape attitudes to homosexual people and homosexuality nationally and internationally. They use hierarchical modeling, with data from the fourth World Values Survey to explore micro and macro effects of religion and cultural orientation.

Just across the Tasman Sea from Australia, Henrickson (2007) conducted a major quantitative study, supported by unsolicited qualitative comments, of 2,269 lesbian, gay, and bisexual New Zealanders on a variety of topics. He reported that lesbian, gay and bisexual New Zealanders have been "disaffiliating with Christianity at 2.37 times the rate of the general New Zealand population since 1966" (p. 1). Those who had been raised as Christians more typically supported that their religion had been a source of difficulty in their lives than a supportive force. Female participants were more likely to believe in a spiritual force than male New Zealanders. Many of the participants in the Henrickson study had chosen their sexual identity over their religious identity and rejected religious faith. Henrickson concludes, however, that "some LGBs have remained connected their religious traditions which demonstrates their resilience and their unwillingness to abandon faith traditions that have in many instances abandoned them" (p. 9).

Schuck and Liddle (2001) found that nearly two thirds of 66 gay, lesbian, and bisexual individuals in their research in the United States had experienced conflict between their religiosity and homosexuality. They concluded that the main sources of conflict for these individuals included denominational teachings, scriptural passages and congregational prejudices that resulted in shame, depression, and suicidal ideation. Many respondents mentioned that their religious denomination considered homosexuality sinful, and that homosexual people were viewed as bad. They stated that a few biblical passages were highlighted to condemn homosexuality, and reported being instructed to pray for forgiveness, making them feel alienated in their own congregations. 
These conflicts have been found to affect homosexual people's cognitive and emotional wellbeing. Schuck and Liddle (2001) suggested that the most damaging consequence of anti-gay teaching was that many homosexual people expressed the feeling that they had been rejected by God and negatively judged by their religious communities. These authors suggested that the cost of feeling rejected by God and negatively judged by surrounding religious communities is considered to be more profound when it happens to adolescents, who are often left with long-term negative emotions such as anger, frustration, and mistrust toward God (Yarhouse \& Tan, 2005).

It has been suggested that homosexual individuals' experiences are bound to encompass a continuum of strategies to achieve reconciliation of the conflict between religiosity and homosexuality (Schuck \& Liddle, 2001). If the homosexual individual happens to come from a close-knit family with strict and conservative religious beliefs, the possibility of losing their family, belief system, and community is so great it could result in the person attempting to alter his or her sexual orientation by undergoing conversion therapy (Haldeman, 2004), although the success of these therapies (along with how ethical they are) is debatable (Herek, 2003; Worthington, 2004).

Those who have had an unsuccessful experience with conversion therapy may feel that they are left with the choice of having to change, challenge, or even abandon their religious or spiritual beliefs in order to meet both their inner-self needs and their homosexuality. If none of the actions taken are able to produce an acceptable (to the individual) outcome, resulting in extreme pressures and stress, a homosexual individual may contemplate or even attempt suicide. There has been evidence linking suicide and homosexual people reporting depression (Kourany, 1987; Kulkin, Chaurin, \& Percle, 2000; Skegg, Nada-Raja, Dickson, Paul, \& Williams, 2003). At the same time, studies by D'Augelli, Hershberger, and Pilkington (2001) and Remafedi, French, Story, Resnick, and Blum (1998) both found greater suicidal ideation and action in gay men as compared to lesbians, which may reflect the more negative attitude and greater victimization directed toward gay men as compared to lesbians (Pilkington \& D’Augelli, 1995).

From a more personal perspective, Ford (2001) shared his own experience when he was faced with the possibility of committing suicide after he was unable to accept the possibility of integrating Christianity and homosexuality. This led him to believe that "living my life as a gay man and going to hell seemed much worse than taking my own life while I was still in grace" (p. 79). This issue suggests that religion can play both protective and damaging roles in the lives of homosexual individuals (Yakushko, 2005).

Barton (2010) used observation, autoethnography, and interviews with 46 lesbians and gay men to explore the experience of living as a gay person in the U.S. Bible Belt, surrounded by very anti-gay evangelical Christians and the associated cultural messages. Participants reported similar feelings of depression, low self-esteem, and worthlessness to those reported in the present study. Australians would consider Australian society to be much more open and tolerant than Bible Belt society; however, the fact that participants in this Australian study grew up within churches and religious contexts may have meant the attitudes and social codes they experienced were more similar to those described by Barton (2010).

\section{THEORETICAL CONSIDERATIONS}

Trying to understand a person's internal experience is a challenging process. The construction of the inner life is unique to an individual (Kelly, 1955); this is influenced 
by the way in which the individual construes the context of the experience and by the environment, which creates meaning for the individual. Mahoney (2002) says "meaning reflects a basic human need for order, relationship and hope whereby these needs are satisfied by being actively sought, co-created and nurtured" (p. 749). In other words, meaning is constructed as a person works to establish an understanding of a situation. Meaning is capable of being a latent variable affecting our cognition, emotion, behavior, and psychological responses (O'Connor, 2003).

In seeking to understand gay men and lesbians' experiences more fully their religious and spiritual lives cannot be denied. Parents' religious and spiritual beliefs are thought to have a direct influence on the way they raise their children regardless of age and life course effects (Myers, 1996). In order to provide support to gay men and lesbians who have experienced, or are currently experiencing, conflict in daily life between their Christianity and their homosexuality, a better understanding of the potential conflict needs to be obtained. Although experiences are unique to individuals and their surroundings, understanding the means by which others have confronted such conflicts would be useful in guiding those who are dealing with such conflict. It can be argued that the disorder that arises from internal conflict is a necessary element in the development of all complex systems such as human beings (Mahoney, 2002); however, such disorder can lead to both positive and negative outcomes for individuals.

Mahaffy (1996) explores the use of the concept of cognitive dissonance, initially developed by Festinger (1957), to explore the ways in which 163 lesbians reconciled their Christian background with their sexual identity. Cognitive dissonance occurs when a person holds two (or more) different, incompatible beliefs at once. A wide variety of different strategies are used to reduce or address the dissonance. Mahaffy identifies internal, external and nonexistent dissonance, and notes that different religious backgrounds tended to lead to different levels of internal and external dissonance, and to different strategies for addressing the dissonance.

Strategies identified in Mahaffy's (1996) study included leaving the church community, changing religious beliefs, and finding ways to live with the dissonance. Similar strategies for dealing with the potential conflict between Christianity and their sexuality were observed in the present study.

Rodriguez (2010) uses the concepts developed in his earlier work (Rodriguez, 2006; Rodriguez \& Ouellette, 2000) of identity conflict and identity integration. Conflict is defined as follows:

I defined the term "conflict" as the tension that can arise between a gay or lesbian Christians' sexual orientation and their religious beliefs ... In hindsight, however, the issue of conflict is not just about the clash that can occur between gay and religious identities, but also about the anxiety that arises in a gay or lesbian person experiencing such conflict. (p. 9)

Drawing on work by Shallenburger (1996, 1998), Rodriguez (2010) also talks about identity integration, a process by which gay men and lesbians discover and evolve in their spiritual identities. The process of coming out to self and others is a key event in this ongoing journey, but it marks only the beginning of the process of integration. Drawing a stronger distinction between religion and spirituality, and ascribing religious opposition to homosexuality to the former is another part of the process. Shallenberger $(1996,1998)$ also explores the processes of questioning, reintegration and reclaiming in relation to spirituality on the part of gay men and lesbians. 
Rodriguez (2010) also addresses the use of cognitive dissonance theory, however he states (following work from Cooper and Fazio [1984] and Jones [1985]), that cognitive dissonance theory remains: "methodologically vague and difficult to operationalize [which] makes cognitive dissonance theory undesirable for use in research studies conducted in this area" (Rodriguez, 2010, p. 13). The area on which Rodriguez is focusing, however, is psychological research, specifically large-scale studies with a quantitative bent, and we feel that the concept of cognitive dissonance as used by Mahaffy (1996) remains useful for making sense of the qualitative data gathered in the present study.

\section{METHOD}

\section{Respondents}

This research study involved 20 homosexual respondents comprising 10 male and 10 female respondents living in the Brisbane City area and surrounding suburbs. At the time of interview, the respondents' ages ranged from 20 to 51 years (mean age 36.5 years old). The mean ages for male and female respondents were 35.4 and 37.5 years old, respectively. The majority of respondents had a high level of education with 18 respondents having completed tertiary degrees (8 males and 10 females). Of the remaining 2 respondents, both male, one possessed a secondary education background while the other possessed a primary education background.

The primary means of recruitment included a) putting up advertisements through flyers; b) publicity through Queer Radio Brisbane (4ZZZ FM102.1); c) direct contact with organizations that serve homosexual people socially (e.g., University of Queensland Queer Collective, Griffith University Queer Collective and Open Doors) or religiously (e.g., Acceptance Brisbane, Metropolitan Community Church and St. Alban's Anglican Church); d) Australian Queer mailing list at ausqueer@yahoo.com; and e) snowballing (i.e., inviting respondents to recruit further respondents). Snowballing was able to assist in locating potentially suitable respondents for interview through other acquaintances.

Respondents belonged to various Christian denominations and were requested to indicate whether they had moved away from their original denomination at the time of interview. Table 1 shows both the denominational backgrounds and the current religious affiliations of all participants. Of the respondents, 11 maintained their original denomination ( 5 males and 6 females), and 9 respondents ( 5 males and 4 females) had moved away from their original denomination. Furthermore, 8 respondents identified as single ( 5 males and 3 females), while the other 12 ( 5 males and 7 females) had partners. Of those with partners, 7 ( 1 male and 6 females) were living with their partner.

\section{Procedure}

This research study was based on voluntary participation. All respondents participated in two in-depth interviews. At the start of the first interview session respondents were briefed about the purpose of the study as well as their rights to confidentiality, anonymity, and to withdraw from the research at any point prior to or during the study. Respondents were informed that if they did decide to withdraw after commencing interviews, any information that had already been collected would be destroyed. Respondents were also given the opportunity to ask questions to clarify any uncertainty 
concerning the study. Written informed consent was obtained from each respondent upon agreement to participate.

Each interview session lasted approximately one hour, with a one-week interval between the two sessions. This structure was chosen due to the sensitivity of the issues being discussed. In order to get sufficient depth in respondents' descriptions of their experiences the researcher needed to engage with respondents in more than a single one hour session (Polkinghorne, 2005; Seidman, 1991).

The first interview focused on the respondents' backgrounds and their perception of their sexual identity. To some extent participants experienced or described fluidity of sexual identity (Subhi et al., 2011), however, at the time of the study, all participants identified as exclusively same-sex attracted. At the same time this first interview also acted as means of developing a strong rapport with the respondents in preparing them for the more intense discussions in the second interview. The second interview focused on the respondents' religious and spiritual development while at the same time exploring the conflict they faced between issues of religiosity and sexual orientation. Here, the researcher also sought to identify how respondents were able to be resilient during times of adversity. The interviews were audio recorded using a digital recorder. The small size of the recorder reduced the level of distraction and the recorded audio files were transferred directly to computer for data analysis.

Analysis

The interviews were analyzed using thematic analysis as outlined by Braun and Clarke (2006) and Boyatzis (1998). Thematic analysis is a method for identifying, analyzing, and reporting themes within findings. Thematic analysis is essentially a method independent of theory and epistemology and can be applied across various theoretical and epistemological approaches. As thematic analysis does not require the detailed theoretical and technological knowledge of approaches such as grounded theory and discourse analysis, it offers more accessibility for novice researchers (Braun \& Clark, 2006). For the purpose of this article, the analysis used was inductive. This means that by using open-ended interview questions, themes were allowed to emerge without presupposing what the important themes would be. In this way, patterns were identified and investigated, assisting the inquirer to understand and make meaning of the data (Patton, 2002). The process of data analysis in this study adhered to the strategy outlined by Creswell (2003). 
TABLE 1 Religious Affiliations and Demographic Characteristics of Participants

\begin{tabular}{|c|c|c|c|c|c|c|}
\hline Pseudonym & Sex & Age (years) & $\begin{array}{l}\text { Educational } \\
\text { background }\end{array}$ & $\begin{array}{l}\text { Original religious } \\
\text { denomination }\end{array}$ & $\begin{array}{c}\text { Current religious } \\
\text { denomination }\end{array}$ & Relationship status \\
\hline Bobby & M & 42 & Primary & Anglican & Follower of Jesus & Single \\
\hline Casey & $\mathrm{F}$ & 22 & Tertiary & Catholic & Catholic & Single \\
\hline Charles & $\mathrm{M}$ & 26 & Tertiary & Uniting & Atheist & Partner \\
\hline Clark & M & 47 & Secondary & Exclusive Brethren & $\begin{array}{l}\text { Nondenominational } \\
\text { Christian }\end{array}$ & Single \\
\hline Ellen & $\mathrm{F}$ & 50 & Tertiary & Anglican & Agnostic & Partner \\
\hline Helena & $\mathrm{F}$ & 35 & Tertiary & Anglican & Anglican & Partner \\
\hline Ivan & $\mathrm{M}$ & 23 & Tertiary & Uniting & Uniting & Single \\
\hline Jason & $\mathrm{M}$ & 40 & Tertiary & Catholic & Catholic & Single \\
\hline Josh & M & 26 & Tertiary & Anglican & Anglican & Partner \\
\hline Jules & M & 39 & Tertiary & Pentecostal & $\begin{array}{l}\text { Metropolitan Community } \\
\text { Church }\end{array}$ & Partner \\
\hline Sandra & $\mathrm{F}$ & 34 & Tertiary & Pentecostal & Pentecostal & Partner \\
\hline Sarah & $\mathrm{F}$ & 51 & Tertiary & Catholic & Atheist & Partner \\
\hline Shawna & $\mathrm{F}$ & 28 & Tertiary & Catholic & Catholic & Single \\
\hline Suzy & $\mathrm{F}$ & 50 & Tertiary & Pentecostal & Solitary female & Single \\
\hline Wynona & $\mathrm{F}$ & 51 & Tertiary & Charismatic & Anglican & Partner \\
\hline
\end{tabular}




\section{RESULTS}

The research study found that a small percentage (20\%, 4 respondents) - all femaledid not experience any conflict between Christianity and homosexuality. Reasons that accounted for respondents not experiencing conflict were a) they had already abandoned Christianity before they came out as a lesbian (3 respondents) or b) they had continued identifying as Christian but were not practicing (1 respondent) and, therefore, not in contact with a particular faith community (and the associated homophobic pressure).

For example, Ellen and Sarah (all names used are pseudonyms) both came from family backgrounds that were not religious but encountered Christianity on their own and became believers. They also both started to have sexual feelings toward their own sex while they were in their teens. They had both left Christianity before fully coming out as lesbians (i.e., they came out to others after they reached adulthood). Ellen explained, "I don't think they overlap because I think I had left that [Christianity] behind before I recognized my [homo] sexuality. So there never was a conflict." Similarly, Sarah stated, "By the time I came out, I was already nonreligious."

Ellen clarified that, for her, Christianity was always associated with social involvement and not religious or spiritual purposes. Her friends were always the driving force behind her religiosity, whether that meant Sunday school, her confirmation as a Christian, or her involvement in a Christian group at school:

...at the age of about 16 I think that I became involved in a Catholic Charismatic movement and that again was because my very close friend at the time, her family was very religious. I became involved in that and I actually enjoyed that; I enjoyed the Charismatic Pentecostal movements, they were very much an uplifting feeling. I ended up going to church on Sundays to the Anglican Church or Church of England where I was confirmed.

Since Ellen comes from a nonreligious family, Christianity was never reinforced at home. When the friendship with her close friend finally came to an end, so did her Christianity. Therefore, when Ellen finally came out as a lesbian the process was easy for her because by then Christianity was no longer part of her belief system as she had left it several years before.

Although Sarah was sent to a Catholic school while growing up, she had difficulty trying to experience faith and God the way the brothers and nuns taught her because she also said she has always viewed the world in a scientific way. Sarah also never had a strong belief in God to begin with, and the little belief she had gradually diminished over the years. By the time she came out as a lesbian, she was already nonreligious and, thus, did not encounter any conflict between her sexuality and her already-discarded Christian beliefs.

Helena also did not experience conflict because she identified herself as a nonpracticing Christian. She came from a family background where her parents were nonreligious. When she was in her teens she had some association with the church through her own initiative but this association was more related to the social activities 
promoted by the church. As she got older she became disillusioned with the church by seeing "different sides of things - that what the church said wasn't particularly what the church did and practiced."

When she came out to herself as a lesbian in her 20s she had already distanced herself from organized religion. Helena identified as belonging to an Anglican denomination whenever she was asked about her Christian background; however, personally she would consider herself as a non-Christian because she believed that she had not given herself to God, which she clarified during the interview:

I was always taught that when you become a Christian that you give your life to God. You stand up in front of a congregation or a group of people and you give your life to God basically and that's what becoming a Christian is. I don't know about other denominations but that's how I was taught. So for me I've not given my life to God I guess I perceived that perhaps I'm not a Christian if that's making sense to you because as I've said I was taught, to become a Christian you have to stand up and be ready and willing to give your life to God and abide by what He had said and what He had written in the Bible and practice the same thing and I didn't do that. I still believed in God, it's just I haven't given my life to Him.

As the result of disengaging herself from being a practicing Christian she did not encounter any real conflict between her Christianity and her homosexuality.

Unlike the $20 \%$ that were unaffected by the conflict, most of the respondents (16 of 20 or $80 \%$ ) faced conflict between Christianity and homosexuality. Findings relating to the experiences that the respondents shared regarding the conflict that they have faced or are still facing are divided into two areas: 1) intrapersonal conflict and 2) interpersonal conflict. While this is a convenient heuristic for discussion, for most of the participants' internal conflicts engendered by pressures from their internalization of the expectations of others were an important facet of intrapersonal conflict. This article focuses on the intrapersonal conflicts reported.

Although each of the respondents who experienced conflict has her or his own unique journey, most identified similar underlying reasons for the intrapersonal conflicts they experienced; that is, they believed that Christianity condemns homosexuality and considers it to be sinful. Jules stated that these socioreligious beliefs were ingrained from a young age and that he viewed homosexuality as something sinful:

It was very challenging . . . because all my life I have been brought up to actually believe that to be gay was abomination to God, to be gay is not right ... that God loves all people but God doesn't want you to be gay and if you are gay you need to do everything in your power to get out of that.

Similarly, Charles was raised to believe that homosexuality was immoral and sinful. Therefore, when he started to experience same-sex feelings and attractions he started to encounter difficulties because these same-sex feelings and attractions contradicted the religious beliefs with which he was raised. After unsuccessful attempts through prayers to remove the same-sex feelings and attractions, Charles started to blame God and accuse Him: 
I was blaming religion a lot and I couldn't understand why God could let me go through something like that. At the time I could not forgive Him or It for what had happened to me and I guess I had pretty fundamentalist views on religion...

For some respondents the conflict between Christianity and homosexuality escalated when it involved significant others around them (e.g., family, friends, or church community). In Wynona's case conflict was amplified when she wanted to start building a relationship with someone of the same sex. After what she described as "a powerful encounter with God" she began a journey of active membership in the church, "I guess God knows how he can touch your heart and get hold of you when he wants to." For the next six years she devoted herself to doing "God's work."

Like others who experienced being active in a church, Wynona tried to suppress her homosexuality by prayer and participating in deliverance ministry. When she later wanted to build a relationship with a woman the conflict was exacerbated because her intention was against the teachings of the Christian church that she belonged to at the time:

I think that is when the conflict really started to manifest because in those six years I wasn't in a relationship in Perth, you see ... I wasn't really confronted with it. I was so involved with church and being busy with that, that I didn't get involved in relationship.

For Shawna, her personal experience of conflict was different from the other respondents who experienced conflict in this research study. In her case, her conflict did not occur prior to or during her coming out process as a lesbian but after she identified herself as a lesbian, while at the same time still wanting to incorporate Christianity in her life:

I would say that the only conflict that I have had is when I am a lesbian and I wanted to then identify as a Catholic. I would have to say that I got more conflict from the gay community or more questions from the gay community about why I would want to be a lesbian and a Catholic.

Shawna stated that in general, friends and colleagues still could not understand her interpretation of Catholicism: "Catholicism is about people and it is not about church as far as I see it." Thus, she found that she had to justify herself when it came to being a Catholic lesbian. Shawna explained her experience of having to interact with friends, the majority of whom are gay and lesbian people-they could not seem to understand why she wanted to cling to Catholicism when to them Catholicism literally condemns homosexuality. Thus, she constantly received criticism, which occasionally appalled her:

I was so taken aback by that, “How dare you tell me what I can and can't identify as!" You're a lesbian and you know how hard it is to be true to yourself. I'm just being true to myself.

Some of the respondents' experiences of conflict were interwoven with the process of coming out to self and others. Jules only came out to himself as a gay man in his adulthood because (he suggested), perhaps subconsciously, he wanted to deny his 
homosexuality. By admitting he was gay he would be seen as opposing the strict Christian upbringing imposed by his very religious mother.

Overall the conflict experienced by these respondents came in various forms and differed from one respondent to the other. If the conflict was extreme, sometimes respondents had to choose between abandoning their Christian beliefs and their homosexuality.

All respondents who indicated that they have experienced or are still experiencing conflict, shared their experiences of the personal effects of the conflict between Christianity and homosexuality. Figure 1 shows the five most common personal effects of conflict between Christianity and homosexuality found in this research were depression ( 11 of 16 or $68.8 \%$ ), self-blame and guilt ( 6 of 16 or $37.5 \%$ ), anxiety ( 5 of 16 or $31.3 \%$ ), suicidal ideation ( 4 of 16 or $25 \%$ ), and alienation ( 4 of 16 or $25 \%)$.

Charles said:

That's something I experienced basically from the age of 14 ... I would say from the age of 14 up until the age of 19 I suffered from severe depression and I didn't even realize it. Do you know what I mean? I just thought that this was normal. I thought it was normal to have this sinking feeling in my gut 24 hours a day but it was so much stuff going through my mind...

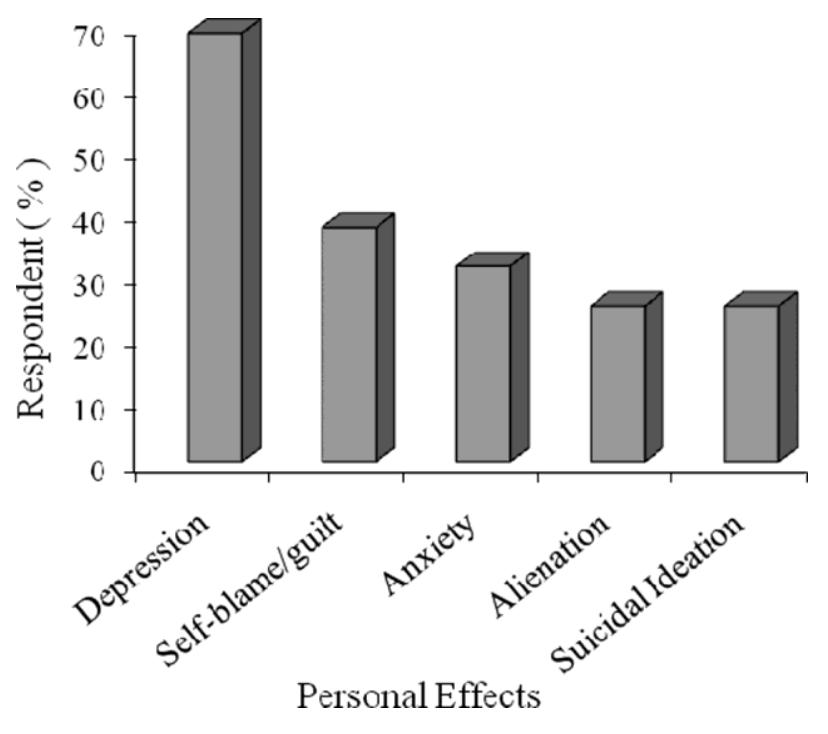

FIGURE 1 Most commonly reported personal effects of conflict between Christianity and homosexuality as stated by respondents $(n=16)$.

Bobby's comments specifically locate his frustration in the cognitive dissonance he was experiencing between his religious and sexual desires:

Yeah, I was depressed. I was depressed because I wanted to serve God and I really wanted to serve God. I was more depressed though that I didn't have control over the desire because I desired to stop having sex with men because I desired to please God. And I was depressed because I could not stop the desire. I didn't have control over it; it was controlling me. It was an addiction and it was strong and it was an addiction and it was like any other addiction. 
It is important to note that when terms such as "depression" and "anxiety" are used in this article they represent the words chosen by respondents themselves to describe their experiences. They are not used in the sense of psychological definitions and diagnoses. Further elaboration of the respondents' personal experiences is presented below. It is also important to note that sometimes it is difficult to highlight a personal effect in isolation because, generally, it is intermingled with other personal effects.

\section{DISCUSSION}

The figure in this research study for the proportion of respondents experiencing conflict between their sexuality and their Christianity (80\%) was higher than at reported by Schuck and Liddle (2001), who reported that $66.7 \%$ of their respondents were affected by the conflict between Christianity and homosexuality. Either figure suggests that this is a serious issue that deserves further research attention.

Generally, the conflict happened as soon as the respondents wanted to embrace both Christianity and homosexuality because they are considered incompatible (McMinn, 2005), and that most mainstream Christian denominations still view homosexuality as immoral and opposed to scripture (Richards \& Bergin, 2000). While arguments have been made that attempt to reject or re-explain the Biblical texts that are claimed to condemn homosexuality (e.g., Myburgh, 2010; Nugent \& Gramick, 1989), these analyses are fiercely contested and have very limited influence in most Christian churches.

The conflict increases if the person comes from a close-knit family with a strong religious background (Newman \& Muzzonigro, 1993). Parents' religiosity is an important factor in facilitating the transmission of religiosity, along with the quality of the family relationship and traditional family structure (Myers, 1996). Myers (1996) argued that parent's religiosity would constantly influence their children's religiosity regardless of age and life course effects.

In the present research study, those who remain somewhere along the continuum between rejecting Christianity and embracing homosexuality or vice versa (i.e., those who are seeking, to varied degrees, to continue being both gay and Christian) are the ones who wanted to maintain their religiosity. These respondents generally came from families with either parent having a moderate to very religious background. These respondents' intention to maintain their Christianity, it can be suggested, might stem from the direct or indirect influence of their parents' religiosity.

When Shawna came out in her 20s, she had problems identifying as a Christian homosexual person. Her mother was the one responsible for giving her the religious guidance and understanding. Shawna's mother said (as reported by Shawna), "Catholic with a small 'C' just means like universal-like that's what Catholicism is."

A few respondents came from strongly religious family backgrounds. Their experience of conflict tended to be more painful and tumultuous in comparison with others who came from more lenient Christian backgrounds (Newman \& Muzzonigro, 1993). For the few respondents - such as Jules, Wynona, and Maria-who have religious parents, the process of coming out to their parents as homosexual was very difficult. There was a lot of anger and resentment from the parents at the time of them coming out. Due to this hostility these respondents had to limit contact or even temporarily sever their relationship with their parents. Basically, for these respondents their parents' religiosity was seen to be influencing their lives well into adulthood. 
The majority of respondents (80\%) wanted to maintain both their Christianity and homosexuality. This figure reflects the findings of Mahaffy's (1996) research with lesbians, who found that $82 \%$ of her respondents maintained their identification as Christians. These findings suggest that both Christianity and homosexuality were important components of the respondents' lives. For a majority of respondents, therefore, it is worth the challenge of struggling through the conflict to harmonize their Christianity and homosexuality.

This study found depression (as described by the respondents themselves) to be the most common individual effect (11of 16, or $68.75 \%$ ) of the conflict between Christianity and homosexuality. Apart from depression, other individual effects described by respondents included self-blame and guilt, anxiety, suicidal ideation, and alienation. The experience of conflict was difficult and demanding and was also described as leaving emotional scars even once the acute conflict had been resolved.

In extreme circumstances, "when all hope is removed" as Clark put it, this conflict could trigger the possibility of gay and lesbian individuals attempting suicide. In the present research study, $25 \%$ of respondents experienced signs of suicidal ideation. All of these respondents also reported experiencing depression. The link between suicide and depression supports previous studies (e.g., Kourany, 1987; Kulkin et al., 2000; Skegg et al., 2003).

Interestingly, only male respondents in this study reported suicidal ideation. This finding reflects those of D'Augelli et al. (2001) and Remafedi et al. (1998) who found suicidal ideation to be more frequent in gay men as compared to lesbians.

At the time of the interviews, all of the respondents seemed to have passed through the most acute and excruciating stage of the conflict (even though some might have not fully resolved the conflict). Some reported that they have taken more time with the struggle (based on the initial starting point of the conflict, which is typically at the time of coming out to self or others) than others.

Coming out is not the end of religious-based conflict but more the beginning: Conflict tends to last from the time of coming out until respondents finally find a set of religious or spiritual beliefs that are congruent with their sexual identity (Shuck \& Liddle, 2001). Some respondents, who were in their 40s and early 50s at the time of interviews, came out at an early age (10-9 years old) as gay men or lesbians. Having begun their struggle in an earlier period of history compared to the younger respondents who were still in their 20s, these older respondents might have had a longer and more difficult experience struggling with the conflict due to the fact that the surrounding environment-in society in general as well as in the churches-was much more homophobic in the past than in the last one to two decades (Loftus, 2001; Yang, 1997).

\section{IMPLICATIONS OF THE RESEARCH STUDY}

The findings of this study have some implications for practice. These are discussed below in relation to a few different groups who may encounter people experiencing conflict between their Christianity and their sexuality.

For counselors and mental health professional, the knowledge that the majority of respondents - selected from among those who self-reported as gay and Christianwere affected by conflict between Christianity and homosexuality, resulting in various personal effects such as depression, self-blame and guilt, anxiety, suicidal ideation, and 
alienation, will potential be of benefit so that they are better equipped to deal with such conflict.

For church leaders, this research study conveys the struggle experienced by Christian homosexual people between their Christianity and homosexuality, and reports the various personal effects experienced. It would be an advantage if church leaders were able to provide a tolerant and safe environment within their congregations for homosexual people who wish to continue having Christianity as a significant part of their lives. By providing such an environment, respondents might feel less alienated within the denomination in which they were brought up. This research study also intends to support opportunities within the church for Christian homosexual people to continue worshipping within their congregation while simultaneously finding means to strengthen their sense of religiosity and spirituality.

For parents, this research study demonstrates that the support of parents is important if they have a loved one who identifies as homosexual. It also reveals that parents who provide a supportive environment and are ready to modify their attitude and beliefs could in fact buffer their gay or lesbian child from facing the worst forms of conflict between Christianity and homosexuality. This need not mean that parents have to change their deeply held beliefs in the importance of Scripture, or in particular ways of interpreting it, but rather suggests changes to their attitudes and behavior toward their adult children.

For homosexual people who are not Christian, or who have felt that they needed to reject their Christianity when they came out, Shawna's experience of feeling rejected by her gay friends because she chose to identify as Christian is important. Research cited in this article and by Rodriguez (2010) shows that a large number of gay people wish to have a Christian religious dimension in their lives, and it can be argued that their religious freedom should be respected.

For Christian homosexual people, having an awareness of others who experience a similar conflict to what they are facing may help to reduce feelings of alienation and anxiety within themselves. Although each experience is unique to a particular respondent, there are bound to be elements that resemble the experiences of other Christian homosexual people. Therefore, this sharing of experiences and knowledge could in fact benefit other Christian homosexual people who are faced with conflict between Christianity and homosexuality.

\section{CONCLUSION}

Even though a few respondents (4 of 20 or 20\%) managed to bypass the conflict between Christianity and homosexuality, the majority of the respondents (16 of 20 or $80 \%$ ) faced conflict between Christianity and homosexuality. For these respondents, both Christianity and homosexuality are considered very important and to live with one without the other would diminish their lives. Depression (11of 16 or $68.8 \%$ ), self-blame and guilt ( 6 or 16 or $37.5 \%$ ), anxiety ( 5 or 16 or $31.3 \%$ ), suicidal ideation ( 4 or 16 or $25 \%$ ) and alienation ( 4 or 16 or $25 \%$ ) were identified as the five most common personal affects of conflict between Christianity and homosexuality for those who experienced it. There remains scope for much further research around this topic, and for significantly enhanced support services for gay Christians experiencing conflict. 


\section{REFERENCES}

Adamczyk, A., \& Pitt, C. (2009). Shaping attitudes about homosexuality: The role of religion and cultural context. Social Science Research 38, 338-351.

Australian Bureau of Statistics. (2006). Year book Australia. Canberra, Australia: Author.

Barret, R., \& Barzan, R. (1996). Spiritual experiences of gay men and lesbians. Counseling and Values, 41, 4-12.

Barret, R., \& Logan, C. (2002). Counseling gay men and lesbians: A practice primer. Pacific Grove, CA: Brooks/ Cole.

Barton, B. (2010). "Abomination"-Life as a Bible belt gay. Journal of Homosexuality, 57 , 465-484.

Boyatzis, R. E. (1998). Transforming qualitative information: Thematic analysis and code development. Thousand Oaks, CA: Sage.

Braun, V., \& Clarke, V. (2006). Using thematic analysis in psychology. Qualitative Research in Psychology, 3, 77-101.

Brooke, H. L. (2005). “Gays, ex-gays, ex-ex-gays: examining key religious, ethical and diversity issues": A follow-up interview with Douglas Haldeman, Ariel Shidlo, Warren Throckmorton, and Mark Yarhouse. Journal of Psychology and Christianity, 24(4), 343-351.

Buchanan, M., Dzelme, K., Harris, D., \& Hecker, L. (2001). Challenges of being simultaneously gay or lesbian and spiritual and/or religious: A narrative perspective. The American Journal of Family Therapy, 29, 435-449.

Cooper, J., \& Fazio, R. (1984). A new look at cognitive dissonance theory. Advances in Experimental Social Psychology, $17,229-265$.

Cresswell, J. W. (2003). Research design: Qualitative, quantitative and mixed methods approaches. Thousand Oaks, CA: Sage.

D’Augelli, A. R., Hershberger, S. L., \& Pilkington, N. W. (2001). Suicidality patterns and sexual orientation-related factors among lesbian, gay, and bisexual youths. Suicide \& Life-Threatening Behavior, 31, 250-264.

Dignity USA. (2008). Statement of position and purpose. Retrieved from http://www.dignityusa.org/purpose

Festinger, L. (1957). A theory of cognitive dissonance. Stanford, CA: Stanford University Press.

Ford, J. G. (2001). Healing homosexuals: A psychologist's journey through the ex-gay movement and the pseudo-science of reparative therapy. Journal of Gay \& Lesbian Psychotherapy, 5(3-4), 69-86.

Haldeman, D. C. (2004). When sexual and religious orientation collide: Considerations in working with conflicted same-sex attracted male clients. The Counseling Psychologist, 32, 691-715.

Helminiak, D. A. (n.d.). FAQs: Catholicism, homosexuality, and Dignity. Retrieved from http://www.integrityusa.org/FAQs/index.htm

Henrickson, M. (2007). A queer kind of faith: Religion and spirituality in lesbian, gay and bisexual New Zealanders. Aoteroa Ethnic Network Journal, 2. Retrieved from http://www.aen.org.nz/journal/2/2/AENJ.2.2.\%20Henricksen.pdf.

Herek, G. M. (2003). Evaluating interventions to alter sexual orientation: Methodological and ethical considerations. Archives of Sexual Behavior, 32, 438-439.

Integrity USA . (2008, June 25). What is Integrity? Retrieved from http://www. integrityusa.org/WhatIsIntegrity/index.htm. 
Jones, E. E. (1985). Major developments in social psychology during the past five decades. In G. Lindzey \& E. Aaronson (Eds.), The handbook of social psychology (3rd ed., pp. 47-108). New York, NY: Random House.

Kelly, G. (1955). The psychology of personal constructs. New York, NY: Norton. Kourany, R. F. (1987). Suicide among homosexual adolescents. Journal of Homosexuality, 13(4), 111-117.

Kulkin, H. S., Chaurin, E. A., \& Percle, G. A. (2000). Suicide among gay and lesbian adolescents and young adults: A review of the literature. Journal of Homosexuality, 40, 1-29.

Loftus, J. (2001). America's liberation in attitudes toward homosexuality, 1973 to 1998. American Sociological Review, 66, 762-782.

Mahaffy, K. A. (1996). Cognitive dissonance and its resolution: A study of lesbian Christians. Journal for the Scientific Study of Religion, 36 , 392-402.

Mahoney, M. J. (2002). Constructivism and positive psychology. In C. R. Snyder \& S. J. Lopez (Eds.), Handbook of positive psychology (pp. 745-750). New York, NY: Oxford University Press.

McMinn, L. G. (2005). Sexual identity concerns for Christian young adults: Practical considerations for being a supportive presence and compassionate companion. Journal of Psychology and Christianity, 24, 368-377.

Moon, D. (2002). Religious views of homosexuality. In D. Richardson \& S. Seidman (Eds.), Handbook of lesbian and gay studies (pp. 313-328). London, UK: Sage. Myburgh, S. J. (2010). Prejudice as moral action in Christian ethical decisionmaking. Verbum et Eclesia, 31(1). Retrieved October 7, 2012, from http://www. ve.org.za/index.php/VE/article/view/89/327

Myers, S. M. (1996). An interactive model of religiosity inheritance: The importance of family context. American Sociological Review, 61, 858-866.

Newman, B. S., \& Muzzonigro, P. G. (1993). The effect of traditional family values on the coming out process of gay male adolescents. Adolescence, 28(109), 213-226.

Nugent, R., \& Gramick, J. (1989). Homosexuality: Protestant, Catholic and Jewish issues; A fishbone tale. Journal of Homosexuality, 18(3), 7-46.

O'Connor, M. F. (2003). Meaning making of life events: Theory, evidence and research directions for an alternative model. OMEGA: Journal of Death and Dying, 46 (1), $51-75$.

Patton, M. Q. (2002). Qualitative research \& evaluation methods (3rd. ed.). Thousand Oaks, CA: Sage.

Pilkington, N. W., \& D'Augelli, A. R. (1995). Victimization of lesbian, gay, and bisexual youth in community settings. Journal of Community Psychology, 23, 34-56.

Polkinghorne, D. E. (2005). Language and meaning: Data collection in qualitative research. Journal of Counseling Psychology, 52, 137-145.

Remafedi, G., French, S., Story, M., Resnick, M. D., \& Blum, R. (1998). The relationship between suicide risk and sexual orientation: Results of a population-based study. American Journal of Public Health, 88, 57-60.

Richards, P. S., \& Bergin, A. E. (2000). Religious diversity and psychotherapy: Conclusions, recommendations, and future directions. In P. S. Richards \& A. E. Bergin (Eds.), Handbook of psychotherapy and religious diversity (pp. 469490). Washington, DC: American Psychology Association.

Rodriguez, E. M. (2006). At the intersection of church and gay: Religion, spirituality, conflict and integration in GLB people of faith. (Doctoral dissertation, CUNY 
Graduate School and University Center, New York, 2006). Dissertation Abstracts International, 67 (3B): 1742

Rodriguez, E.M. (2010) At the intersection of church and gay: A review of the psychological research on gay and lesbian Christians, Journal of Homosexuality, 57 (1), 5-38.

Rodriguez, E. M., \& Ouellette, S. C. (2000). Gay and lesbian Christians: Homosexual and religious identity integration in the members and participants of a gay-positive church. Journal for the Scientific Study of Religion, 39, 333-347.

Schuck, K. D., \& Liddle, B. J. (2001). Religious conflicts experienced by lesbian, gay and bisexual individuals. Journal of Gay and Lesbian Psychotherapy, 5, 63-82. Seidman, I. E. (1991). Interviewing as qualitative research. New York, NY: Teachers College Press.

Shallenberger, D. (1996). Reclaiming the spirit: The journeys of gay men and lesbian women toward integration. Qualitative Sociology, 19, 195-215.

Shallenberger, D. (1998). Reclaiming the spirit: Gay men and lesbians come to terms with religion. New Brunswick, NJ: Rutgers University Press.

Skegg, K., Nada-Raja, S., Dickson, N., Paul, C., \& Williams, S. (2003). Sexual orientation and self-harm in men and women. The American Journal of Psychiatry, 160, 541-546.

Subhi, N. (2006). The potential conflict between religiosity and sexual orientation impacting on gay men: A better understanding through the resilience framework. Paper presented at the 2006 Joint Conference of the APS and NZPsS, Auckland, New Zealand, September 26-30.

Subhi, N., Geelan, D., Nen, S., Fauziah, I., Mohamad, M. S., Lukman, Z. M., Rusyda, H. M. (2011). Sexual identity and sexual fluidity among gay men and lesbians. Pertanika Journal of the Social Science and Humanities, 19(Suppl.), 163-172.

Worthington, R. L. (2004). Sexual identity, sexual orientation, religious identity, and change: Is it possible to depolarize the debate? The Counseling Psychologist, 32, 741-749.

Yakushko, 0. (2005). Influence of social support, existential well-being, and stress over sexual orientation on self esteem of gay, lesbian and bisexual individuals. International Journal for the Advancement of Counselling, 27 , 131-143.

Yang, A. S. (1997). The poles-trends: Attitudes toward homosexuality. Public Opinion Quarterly, 61, 477-507.

Yarhouse, M. A., Brooke, H. L., Pisano, P., \& Tan, E. S. N. (2005). Project inner compass: Young adults experiencing sexual identity confusion. Journal of Psychology and Christianity, 24, 352-360.

Yarhouse, M. A., \& Tan, E. S. N. (2005). Addressing religious conflicts in adolescents who experience sexual identity confusion. Professional Psychology, 36 , 530-536.

Yarhouse, M. A., Tan, E. S. N., \& Pawlowski, L. M. (2005). Sexual identity development and synthesis among LGB-identified and LGB dis-identified persons. Journal of Psychology and Theology, 33, 3-16. 